\title{
Interfaces
}

\section{Textual Illustration Of Images In Claudio Cambon's Shipbreak}

\section{Brittain Smith}

\section{Q OpenEdition \\ 1 Journals}

\section{Electronic version}

URL: http://journals.openedition.org/interfaces/325

DOI: 10.4000/interfaces.325

ISSN: 2647-6754

\section{Publisher:}

Université de Bourgogne, Université de Paris, College of the Holy Cross

\section{Printed version}

Date of publication: 1 January 2017

Number of pages: 223-248

ISSN: $1164-6225$

\section{Electronic reference}

Brittain Smith, "Textual Illustration Of Images In Claudio Cambon's Shipbreak", Interfaces [Online], 38 |

2017, Online since 13 June 2018, connection on 07 January 2021. URL: http://

journals.openedition.org/interfaces/325 ; DOI: https://doi.org/10.4000/interfaces.325

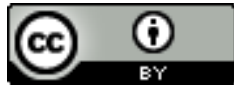

Les contenus de la revue Interfaces sont mis à disposition selon les termes de la Licence Creative Commons Attribution 4.0 International. 


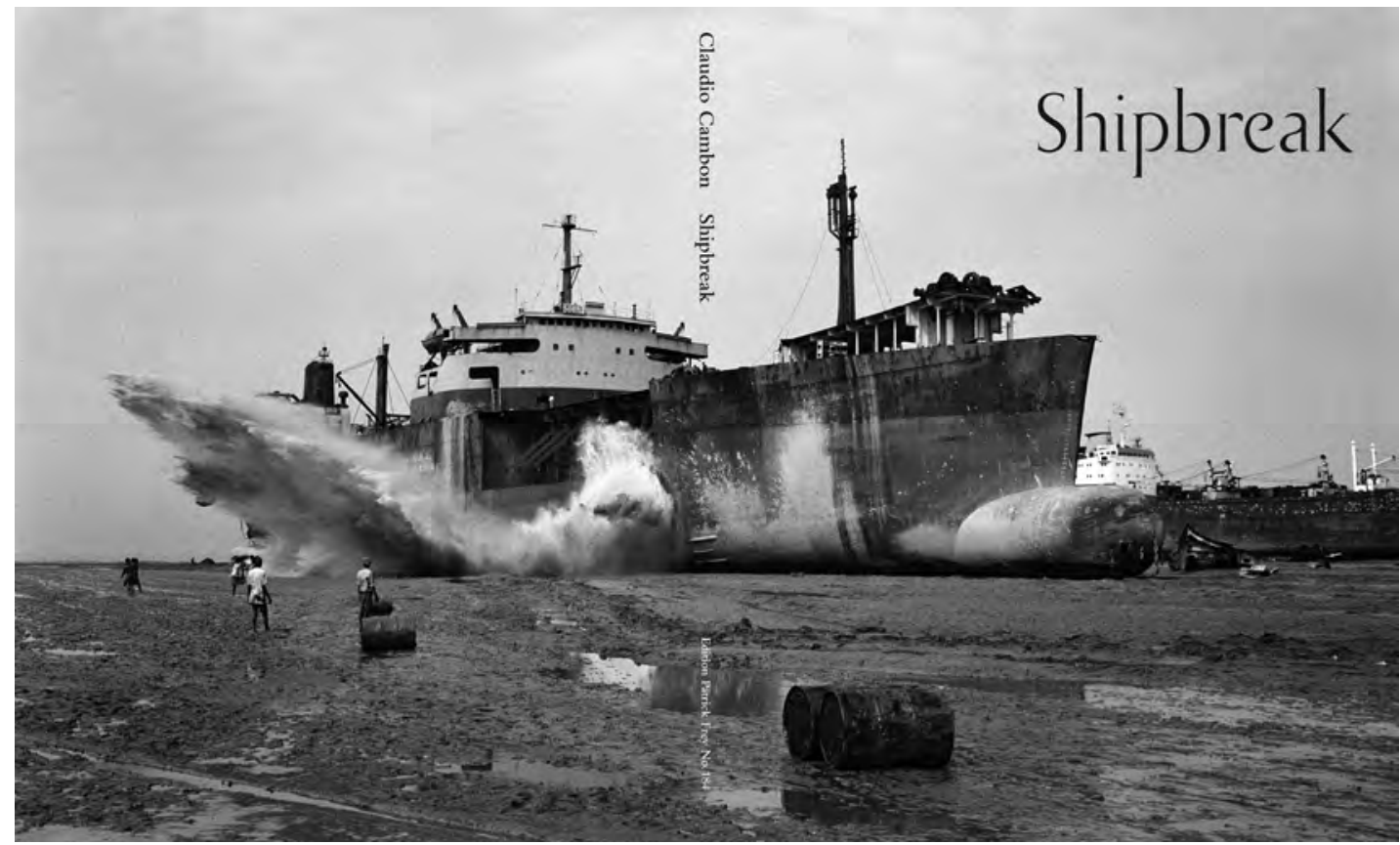

Fig. 1. Shipbreak, Jacket Cover

\section{TEXTUAL ILLUSTRATION OF IMAGES IN CLAUDIO CAMBON'S SHIPBREAK}

\section{Brittain Smith}

In November of 1997, the documentary photographer and author, Claudio Cambon, boards the U.S. merchant marine vessel, the SS Minole, at an old, dilapidated dock in Violet, Louisiana just south of New Orleans. After thirty-seven years of service logging millions of nautical miles, the Minole is about to depart on its last voyage. Still in spectacular shape, the Minole has, in the wake of the catastrophic Exxon Valdez oil spill, been condemned to an early death by legislation that banned single hull oil tankers. Cambon would keep a photographic record of the Minole's final voyage of 13,200 nautical miles to Chitagong, Bangladesh, carrying 43,300 metric tons of wheat for the U.S. Agency for International Development's “food for peace” program (p.105). 
In Chitagong, after its cargo had been unloaded, the enormous ship was run aground and demolished, more or less by hand, over a period of five months. The Minole's raw materials were reused in countless ways, enacting "a kind of reincarnation" (Shipbreak, jacket notes). Cambon documented this journey in a series of stunning black and white photographs. He then, over a decade and half later, created a compelling narrative to accompany the images for the book under review, namely Shipbreak, but it is important to keep in mind that this is truly an instance of "prima l'immagine dopo la parola." In Shipbreak, language acts as an appropriation and illustration of image. The book's thoughtful design recreates this process by placing the images first, then the text, but the book also re-appropriates the text as image by turning portions of the text itself into quasi images on a single page in enlarged script. Fig. 2. For additional such "textual images" of varying font sizes, see pages 109, 117, 121, 129, 133, 137, 143, 147. For future reference, please note in Fig. 2 the waves that mark divisions in the text.

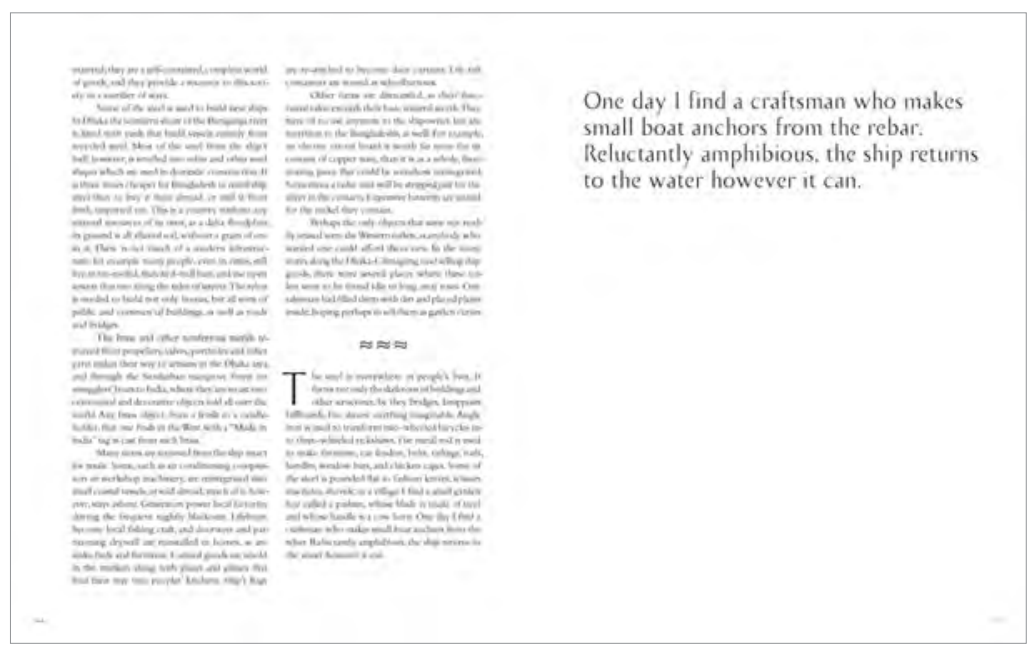

Fig. 2. Shipbreak, pages 144-145

I want to try to recreate here in breve the viewer's / reader's experience of Shipbreak by first presenting a selection of the images. Afterwards, I'll let Cambon's language illustrate the images and provide a few observations of my own. Cheating a little, I'll say that the ensuing images fall under the headings of crew ( Figs. 3-6 ) voyage ( Figs. 7-9), arrival ( Fig. 10 ), unloading ( Figs. 1115 ), shipbreak or death ( Figs. 16-19 ). I'll withhold for later images for the "final" stage, namely reincarnation. 
Fig. 3. Roger Organ,

Chief Cook and

Chief Steward
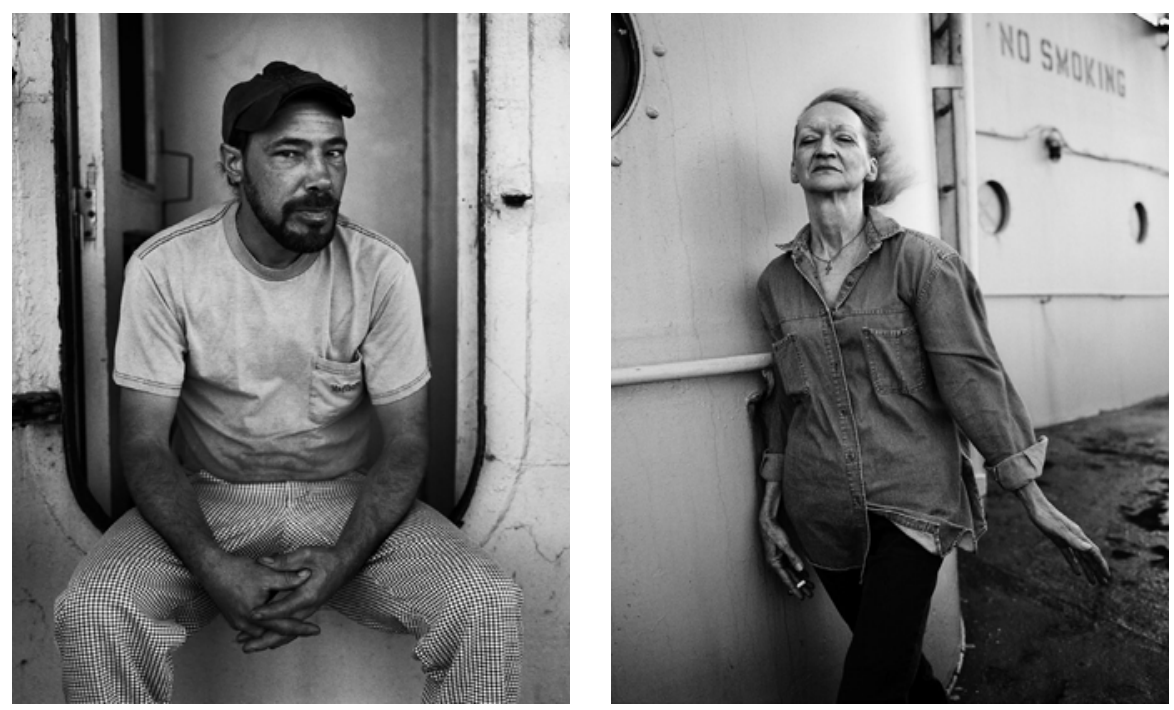

Fig. 4. June Emerson, Assistant Cook

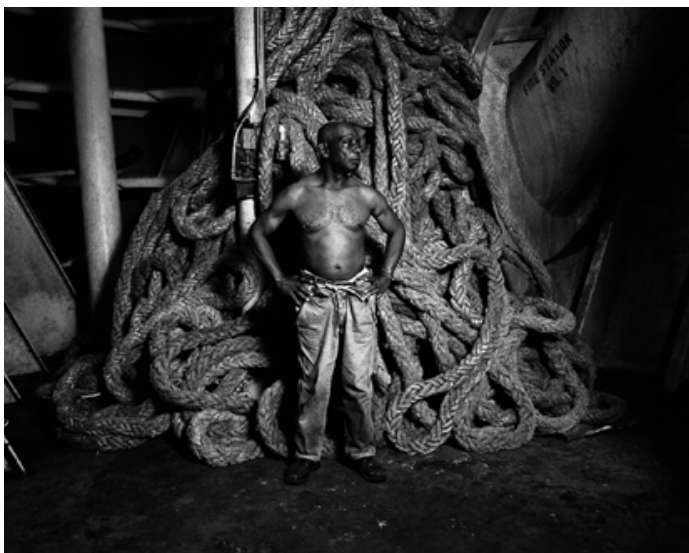

Fig. 5. 'Papa' John Wallace, Bosun

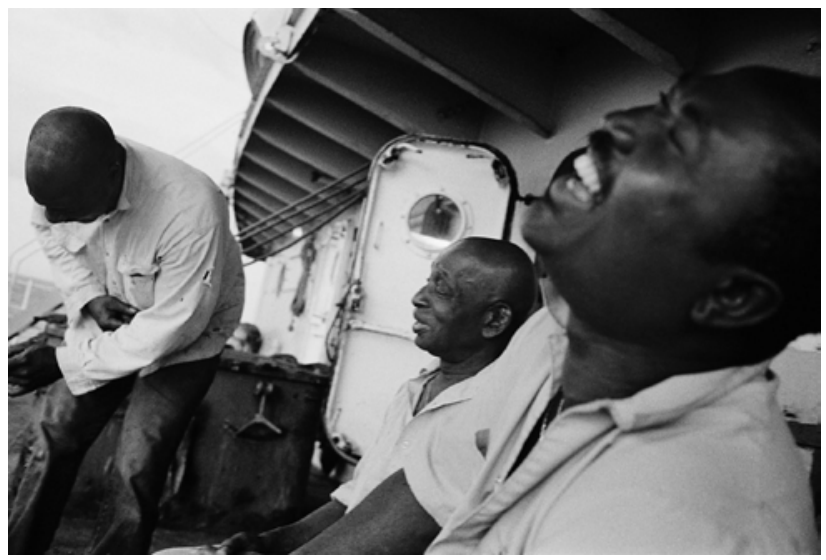

Fig. 6. Out on the fantail after dinner 


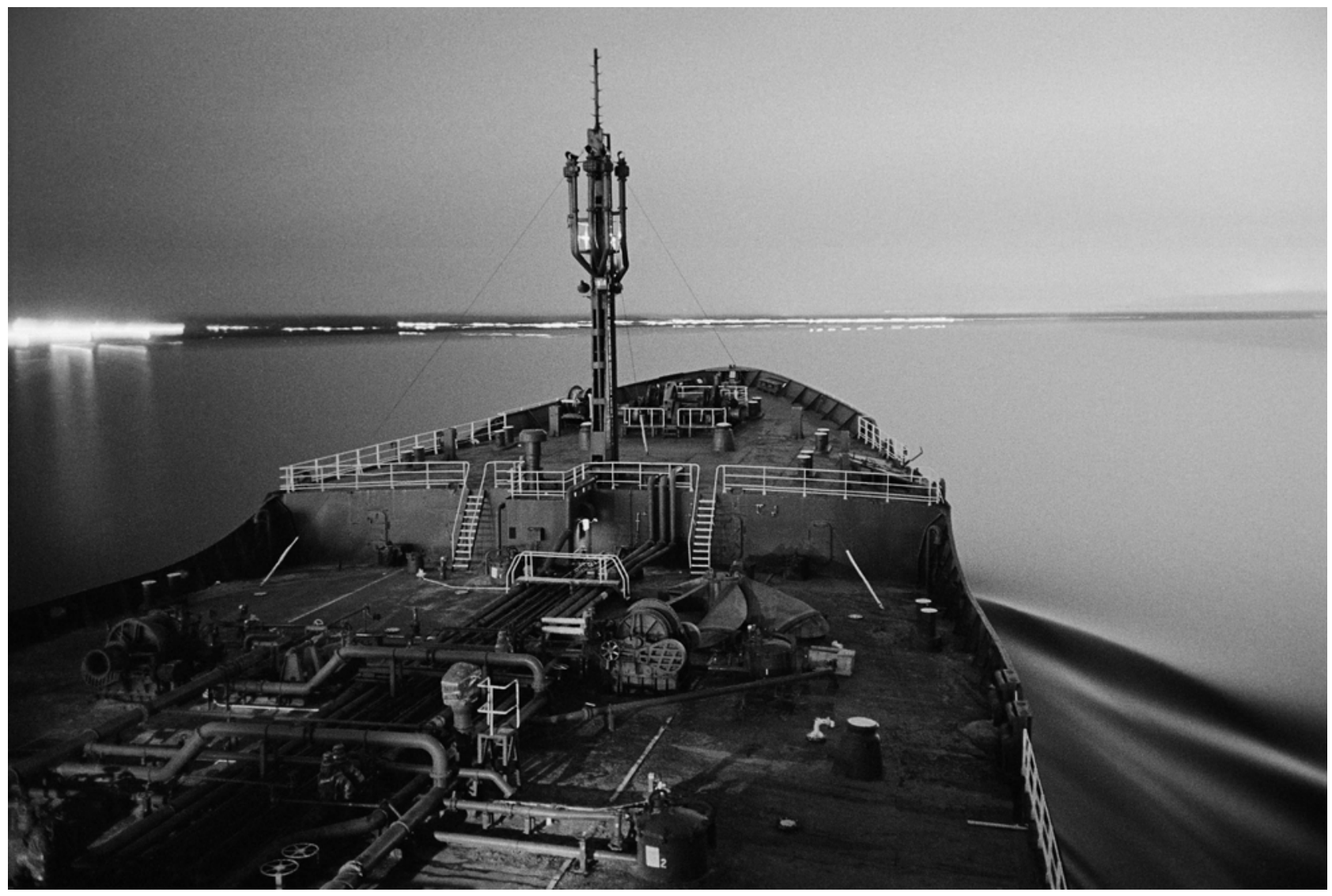

Fig. 7. Heading down the Mississippi River 

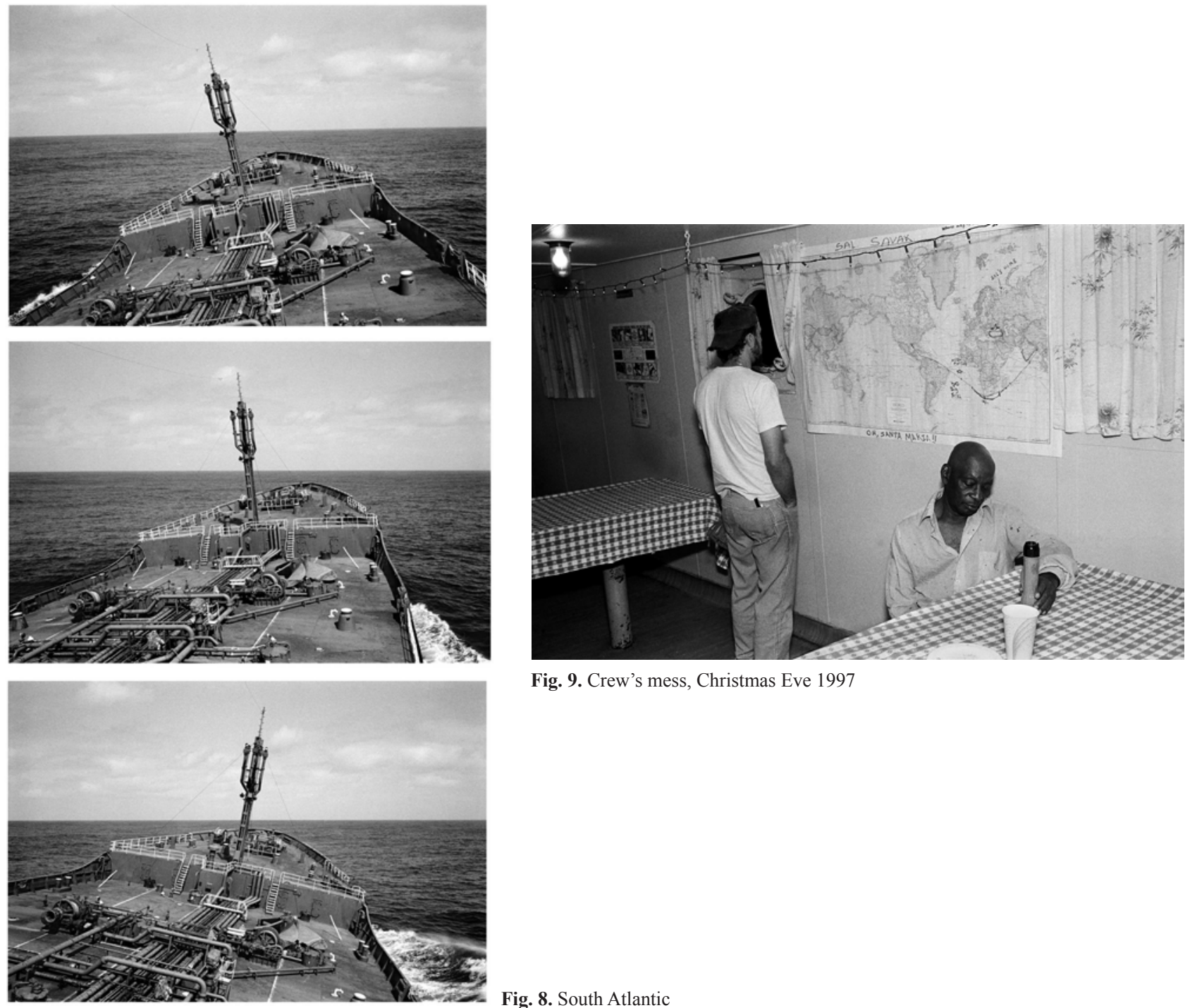

Fig. 9. Crew's mess, Christmas Eve 1997

Fig. 8. South Atlantic 


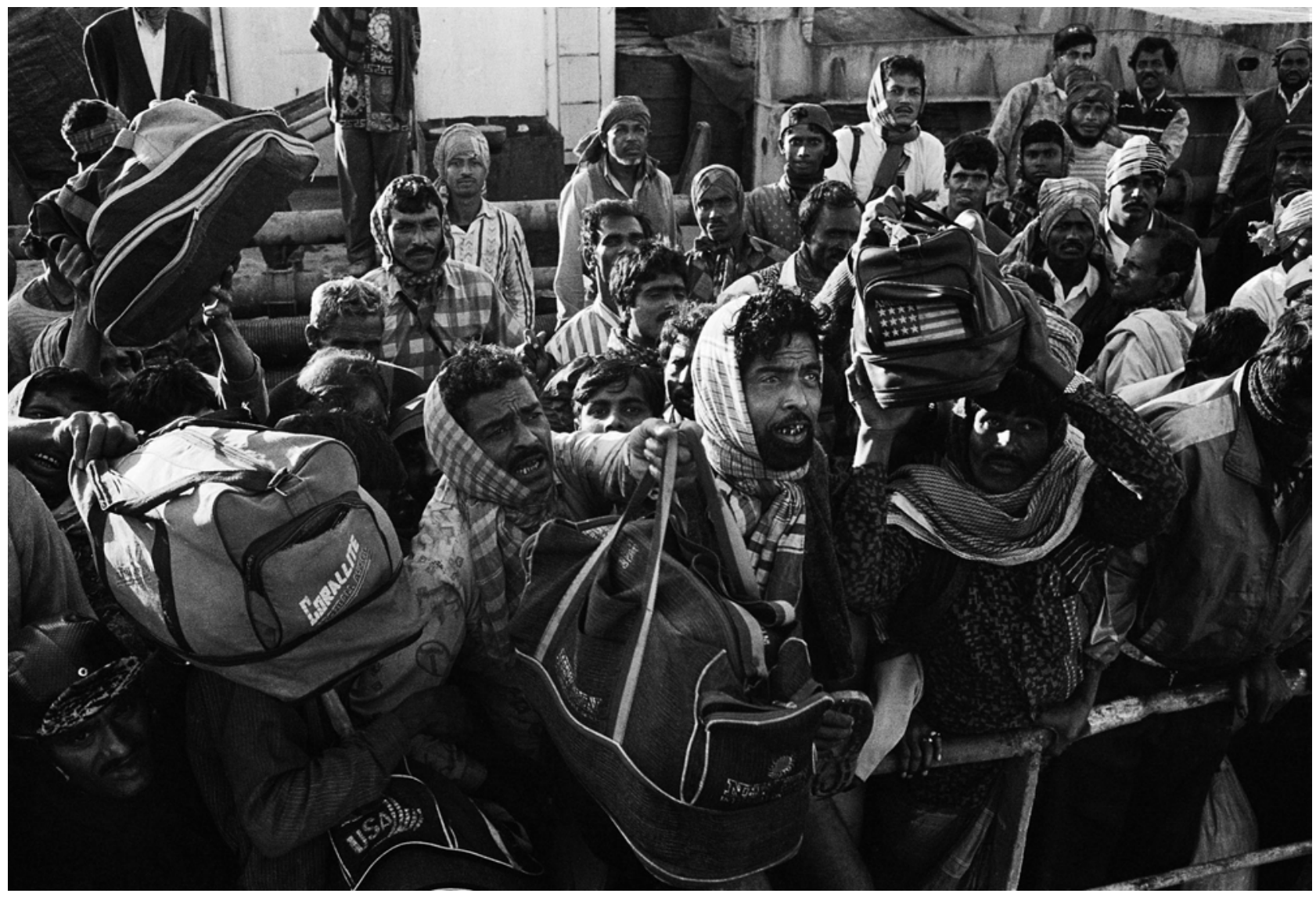

Fig.10. Longshoremen board the SS Minole at anchorage off Kutubdia Island, Bangladesh, December 27, 1997 


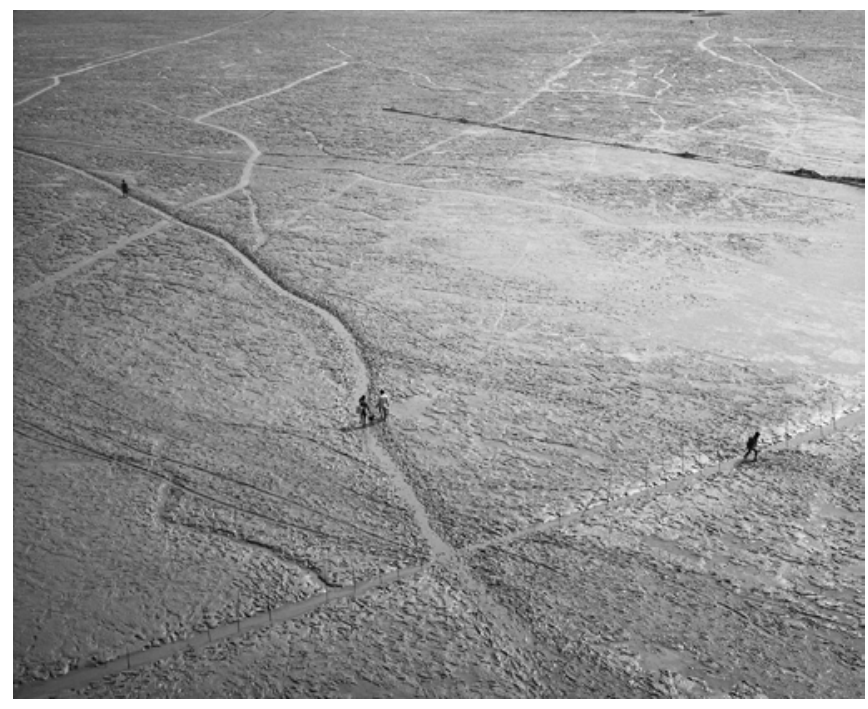

Fig. 11.

Untitled,

pages $48-49$

Fig. 12. Inj.d workers (1)

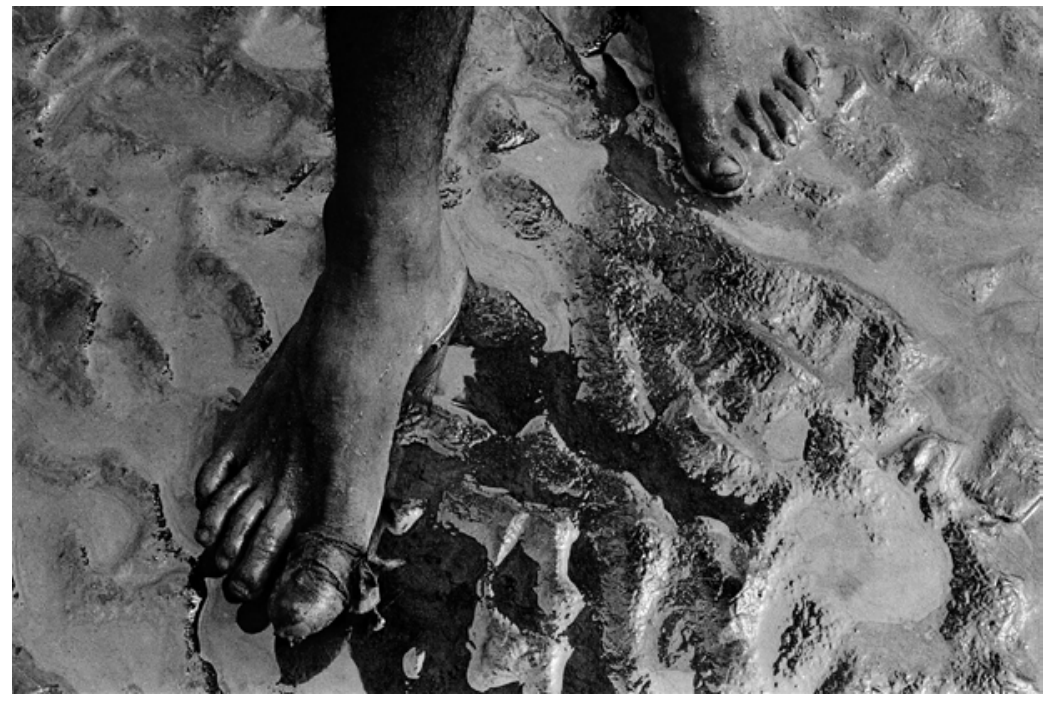




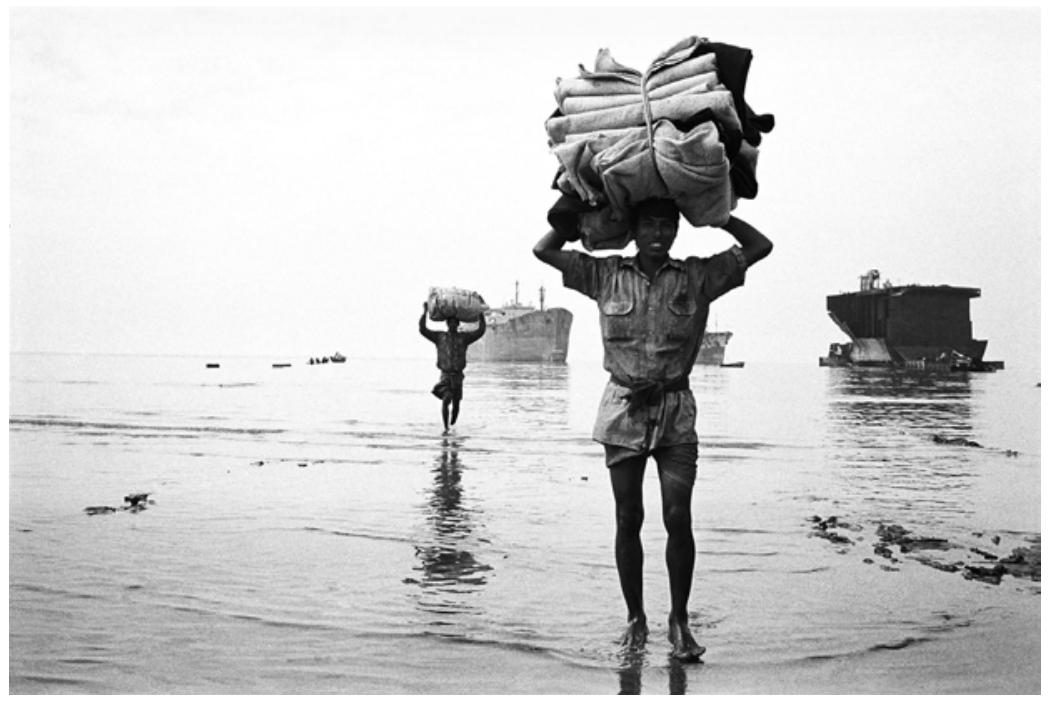

Fig. 13.

Offloading the ship's contents (1)

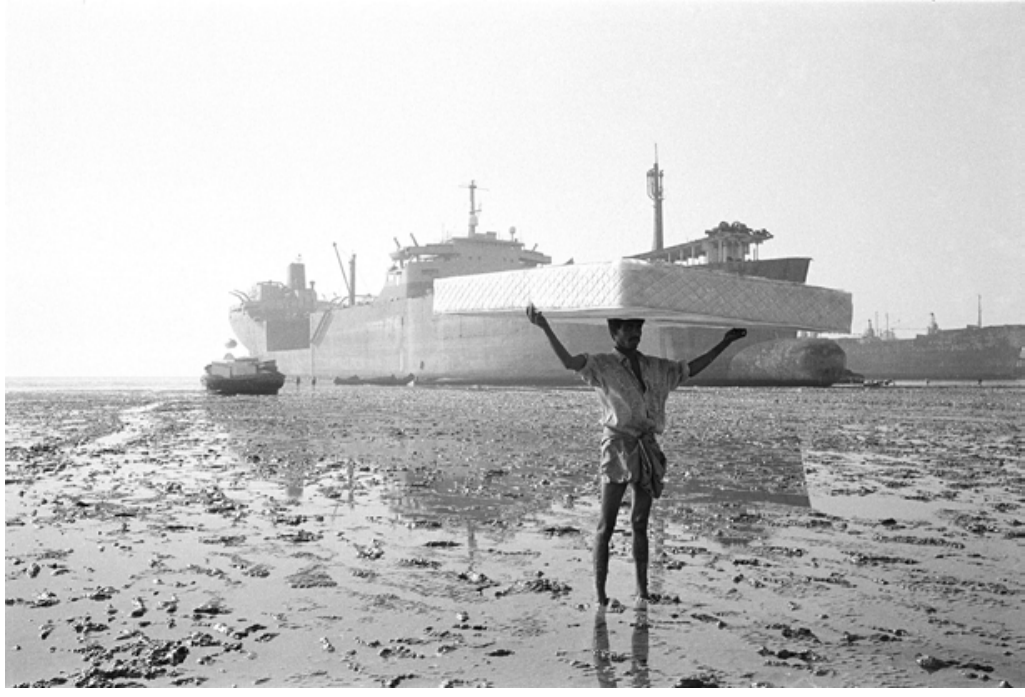

Fig. 14.

Offloading the ship's contents (2) 


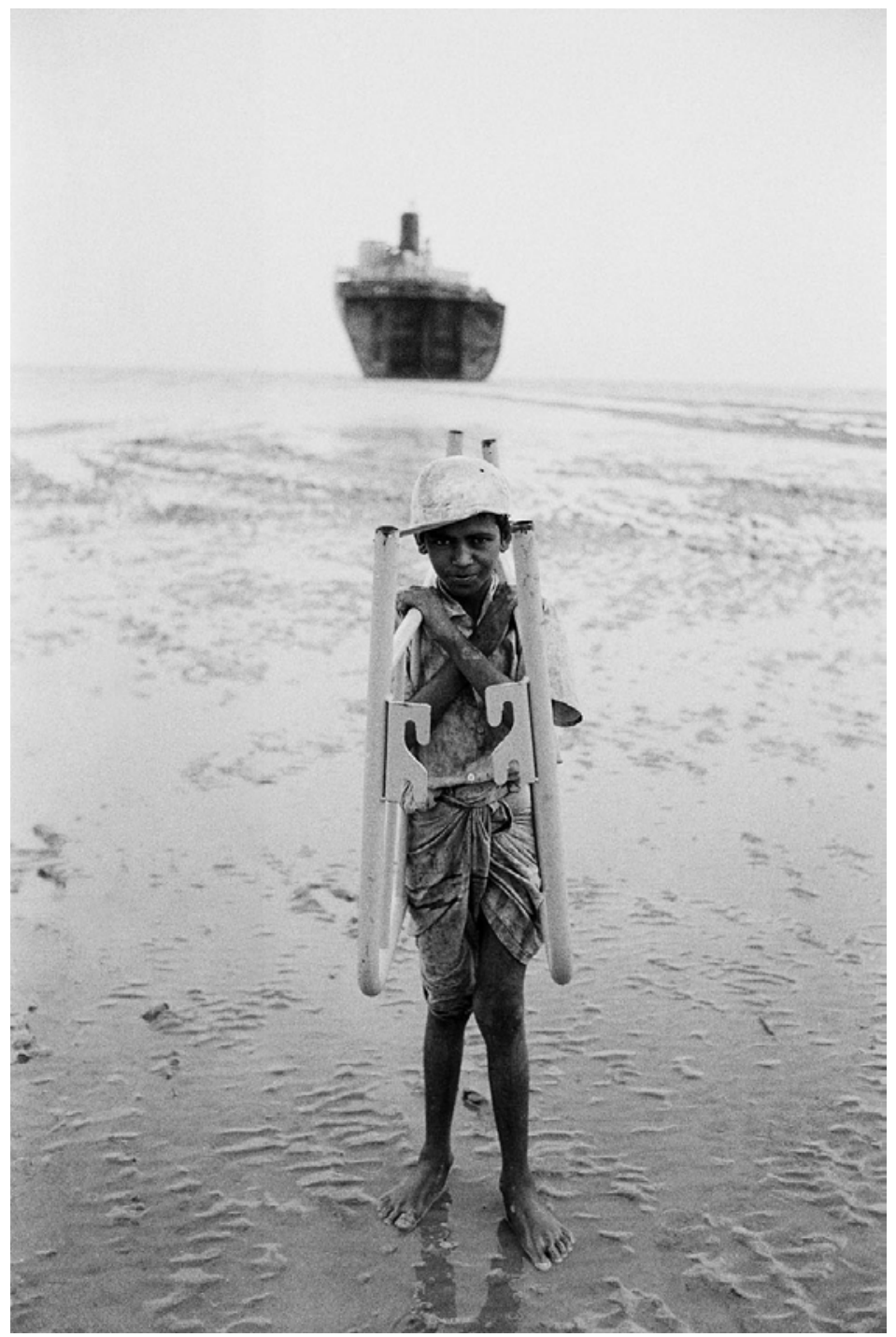

Fig. 15. Kholil, age 11 , carries a bedframe 


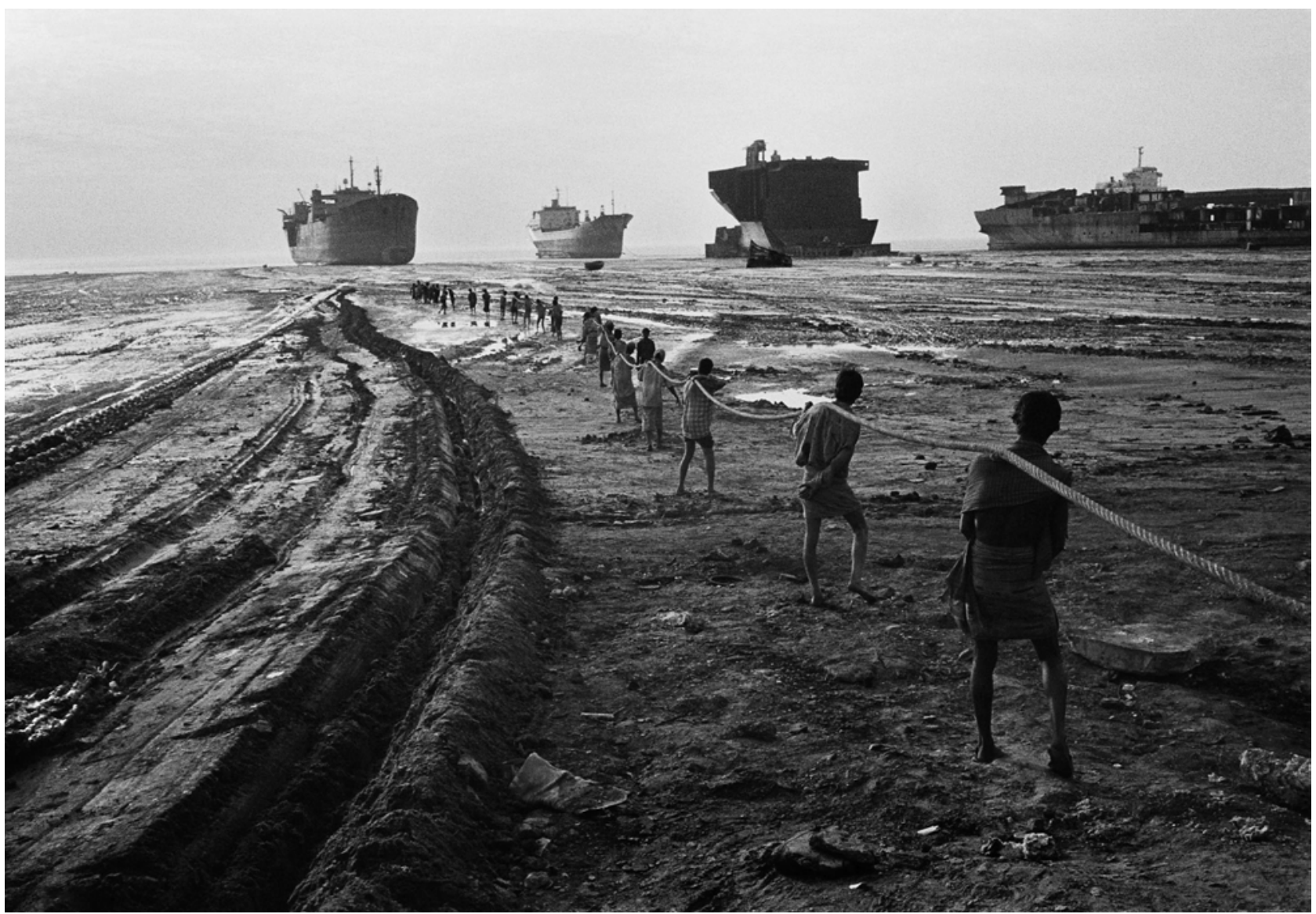

Fig. 16. 'Wire carriers' move cable to the ship to retrieve a felled chunk 


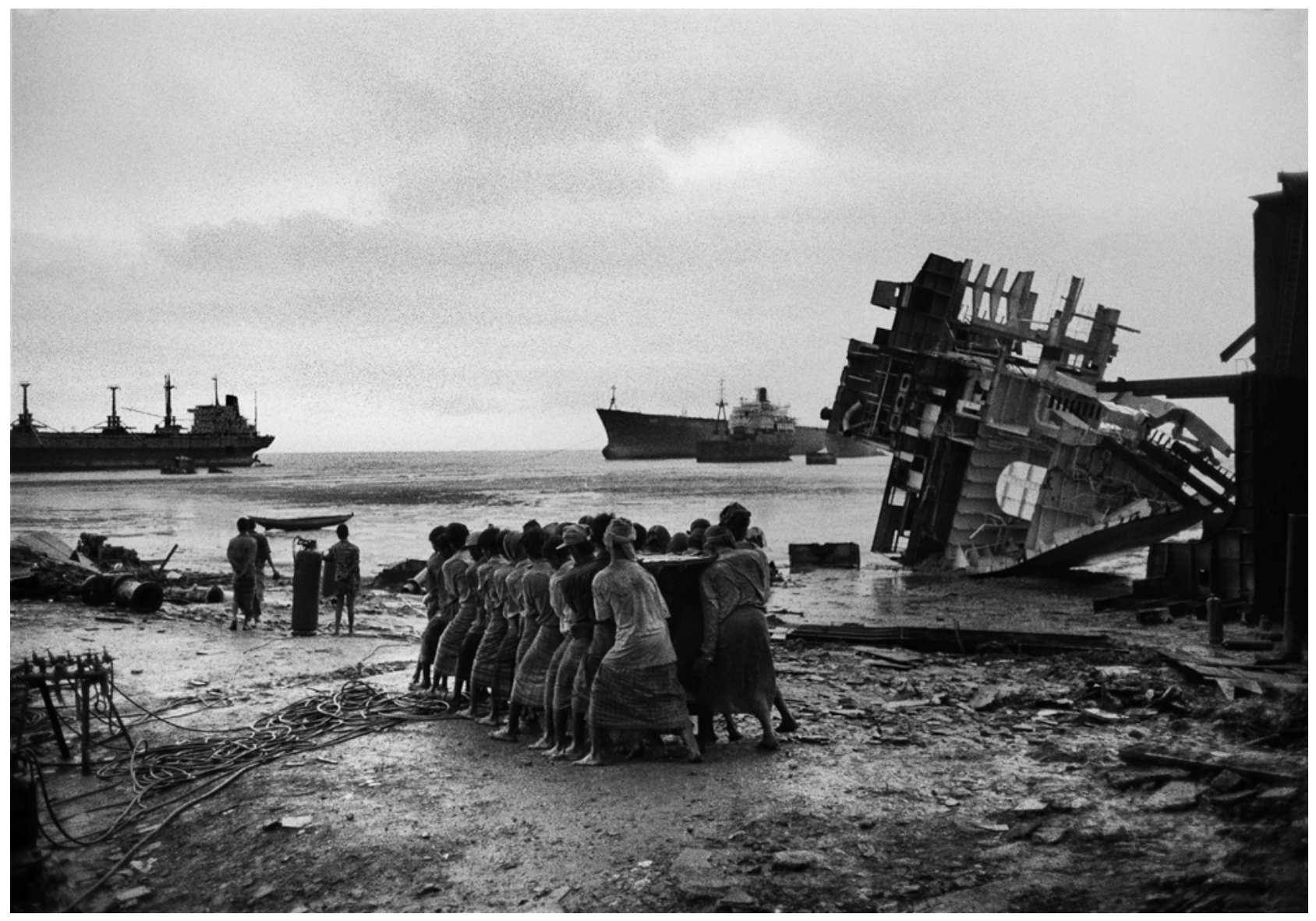

Fig. 17. Loaders, monsoon 


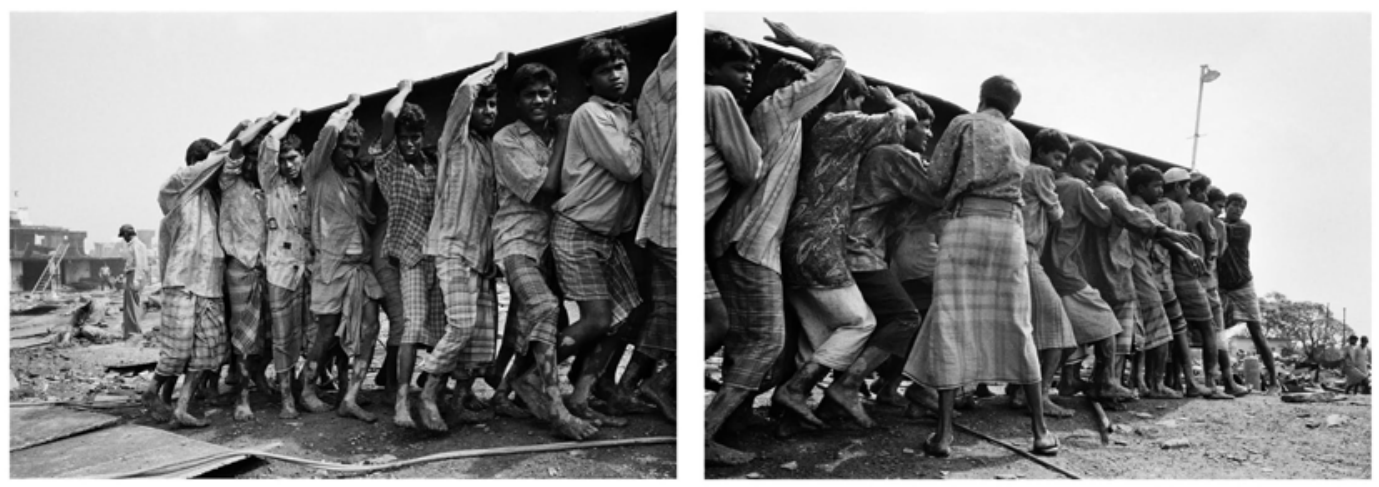

Fig. 18. Loaders, frieze

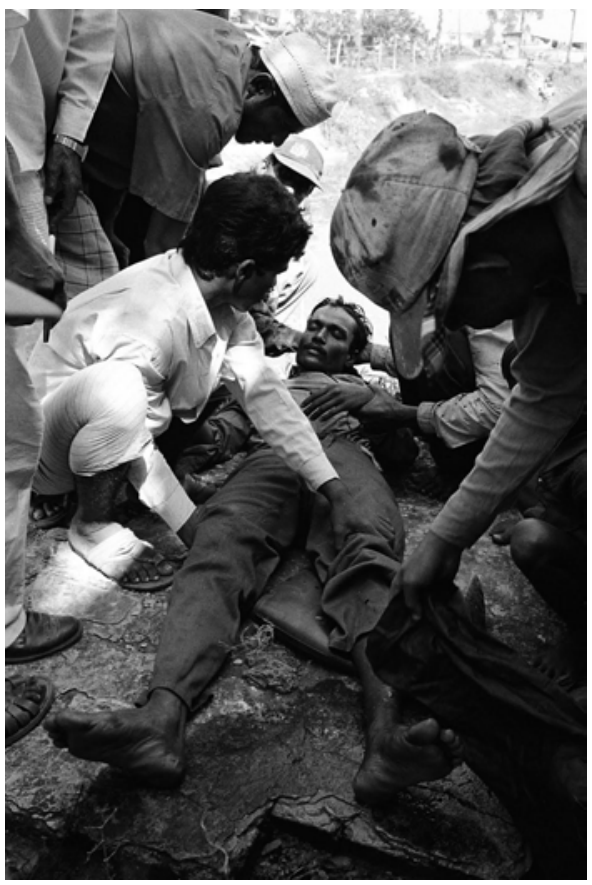

Fig. 19. Inj.d workers (2) 
Shipbreak, the book, operates with a number of conceits. The first is that ships have a life, a fact accentuated by Cambon's constant reference to the Minole as "she." More precisely, ships are, in Cambon's words, "an emblem [emphasis added] of life itself" (p.9). The original title of the project was "The Biology of Steel": Note the vertebra-esque chain in Fig. 20. Ships have a birth (Fig. 21 )and a death ( Fig. 22 ), a beached whale if ever there was one. Cambon refers to the cutters and wire carriers you see in Fig. 23 as "precarious acrobats" (p.128), but it takes only a small leap of imagination to view them also as crows picking at carrion flesh. From the book we read:

On January 14, 1998 at 2:20 p.m., the steamship Minole beached in the breaking yards of Fahad Steel Industries [...] She crossed the sand bar and plowed to a standstill in the shallow water of the beaching plain [...] Like an animal shuddering in the throws of death, she slowly vibrated to a halt in that mud $[\ldots]$ The engineers shut off her fuel line; she choked and gasped, belching one last, thick cloud of black smoke, and then she died (p.126).

Again birth: "Launch day, Sparrow’s Point Shipyard, Baltimore 1961” (p.6) and Fig. 21. And from the text, birth and death:

In November 1961[...] Jane McQuilkin, the ship's sponsor, smashed a bottle of red wine across her hull to launch her; on January 15, 1998, the cutting foreman and an Imam smear the blood of a sacrificed goat in various places of the ship to bless her and the workers, to protect them from harm. She ended her travels here (p.127).

Not only is there life and death, the Minole has a particular life and is emblematic of a distinct historical epoch.

She had the same aesthetic as old fifties cars. She felt solid and luxurious with few hard edges or right angles $[\ldots]$ One has the impression that no expense was spared to build her well and beautifully (p.107).

The demise of the Minole, then, marks the passing of an era and not just of industrial production:

The Minole was a relic of an era of greater certainty and ease.

Forty years ago, sailors were sure of their ship and their jobs;

both seemed capable of lasting indefinitely [...] To see her decommissioned was to bid farewell to a whole period in shipping, a more confident time (p.107). 

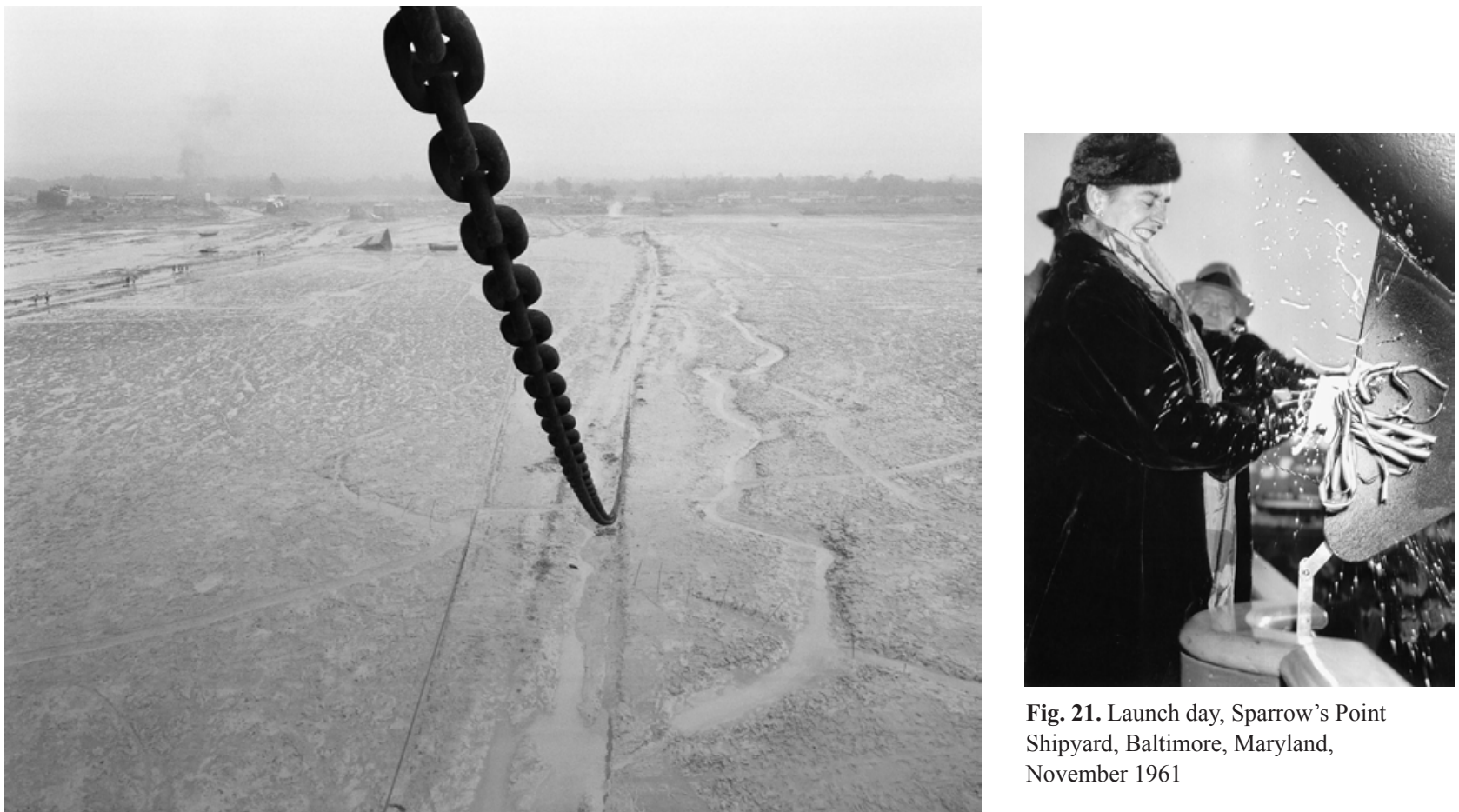

Fig. 21. Launch day, Sparrow's Point Shipyard, Baltimore, Maryland, November 1961

Fig. 20. Anchor chain paid out 


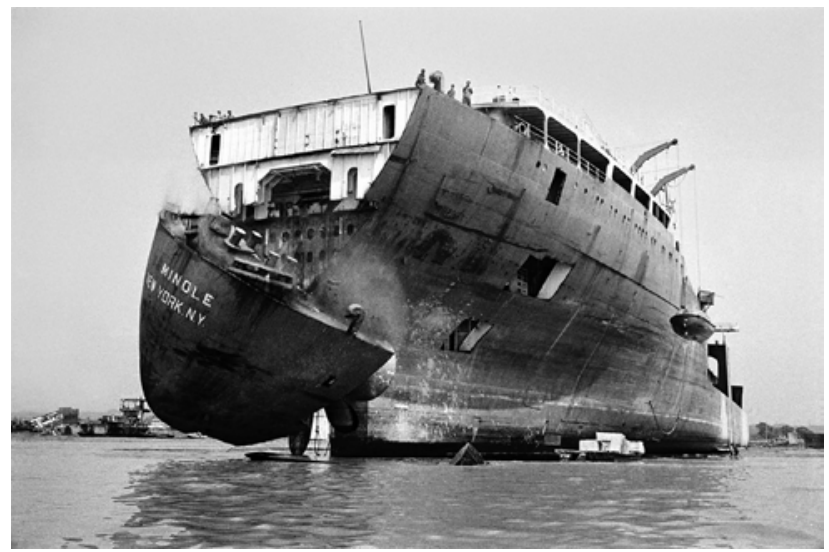

Fig. 22. Untitled, pages 58-59.

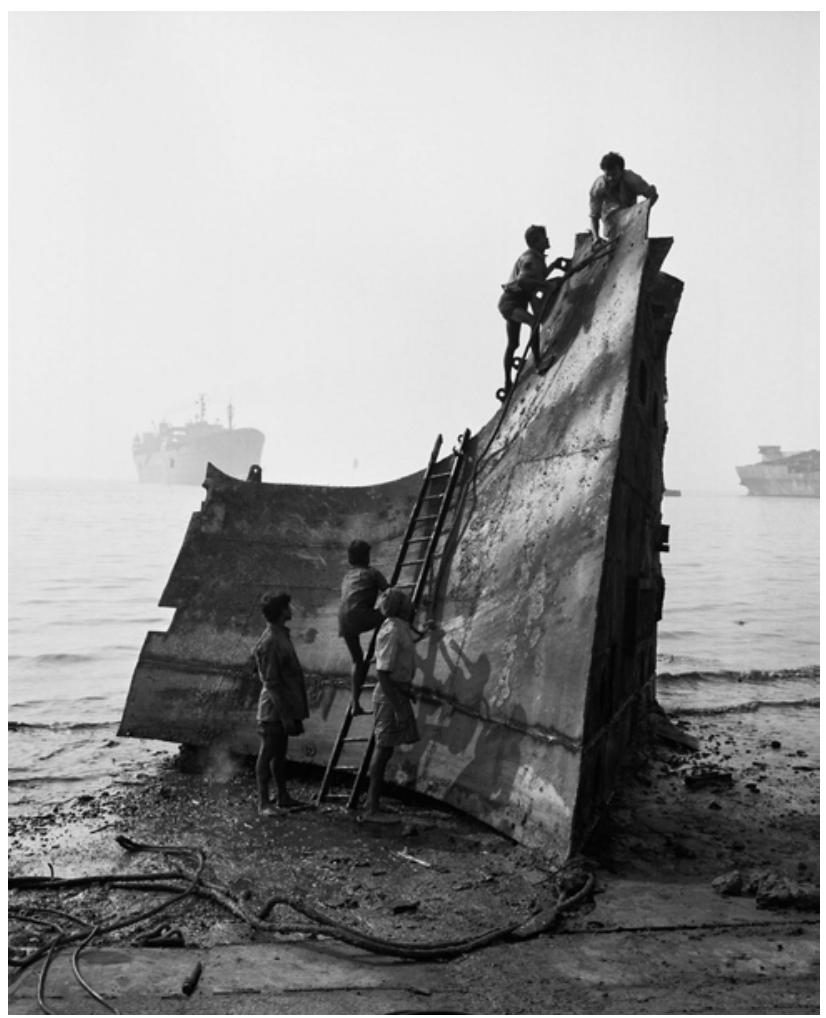

Fig. 23. The beaching of the SS Minole,

January 14, 2.20 PM, Lalbagh, Bangladesh 
I think you can also see the effects of a dying industry on the crew: Figure 24 and Figures 3-6.

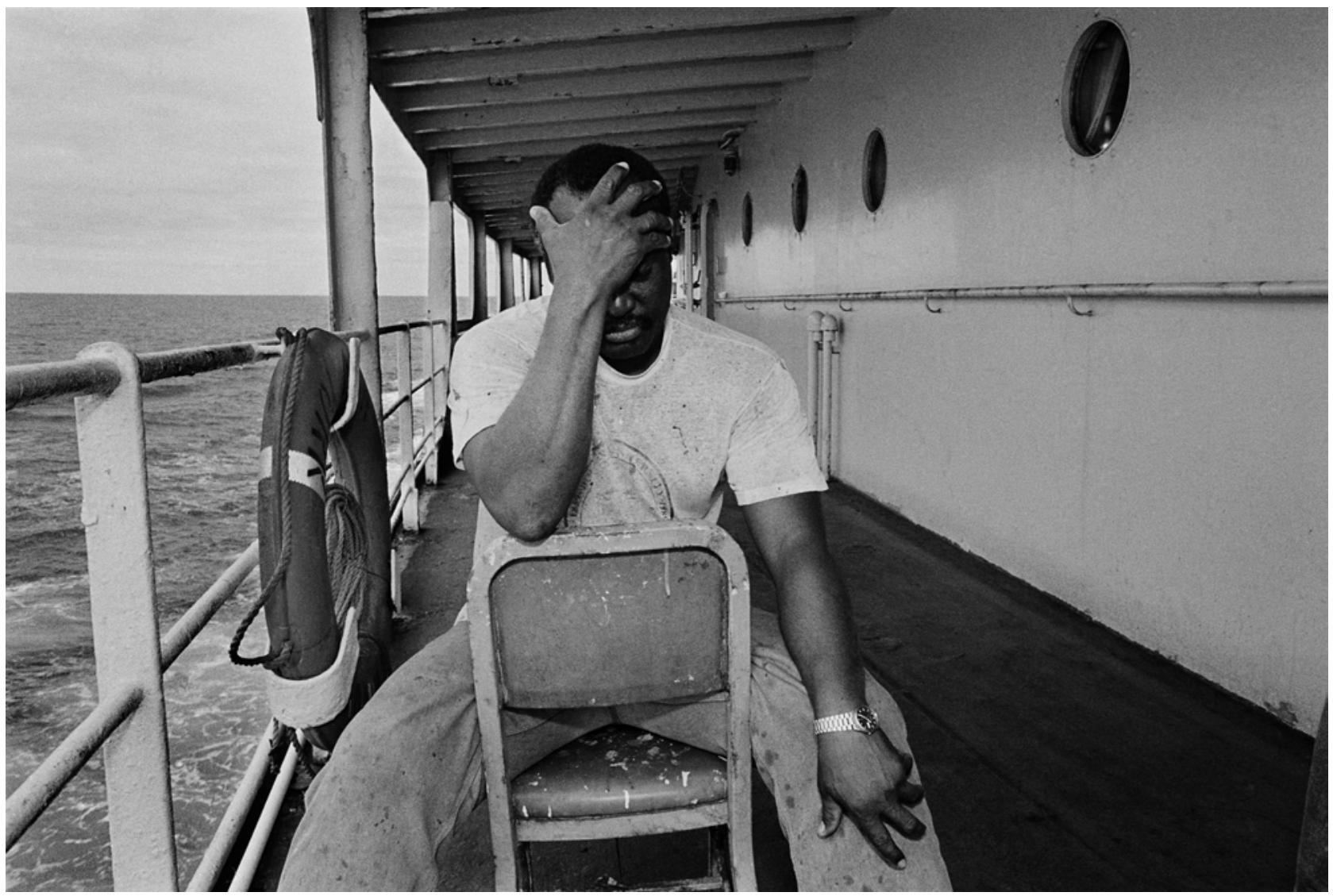

Fig. 24. Noah Tanihu, AB Seaman 
Ships are not only an emblem of life, a particular life in a particular time, they are, Shipbreak argues, also emblems of transcendence:

Many peoples through the ages, from the Egyptians to the Vikings and beyond, have buried their dead in boats...they believed would transport them into the afterlife. The footprint of the Christian church is modeled symbolically on the proportions of Noah's ark; hence the "nave" of the church which comes from navis, the Latin for "ship." The Minole has ferried herself into an afterlife, but not one that I initially want to recognize. It seems like hell at first to see her so abandoned to be cannibalized; slowly, though, I begin to witness her own transcendence (p.127). Figs. 25-26

Transcendence, literally "ascending beyond," takes the humble and, as we shall see, not so humble form of recycling: Cambon informs us that Bangladesh positively thrives on recycling. He also recounts:

One day I find a craftsman who makes small boat anchors from the rebar [derived from the ship's hull]. Reluctantly amphibious, the ship returns to the water however [she] can" (p. 145).

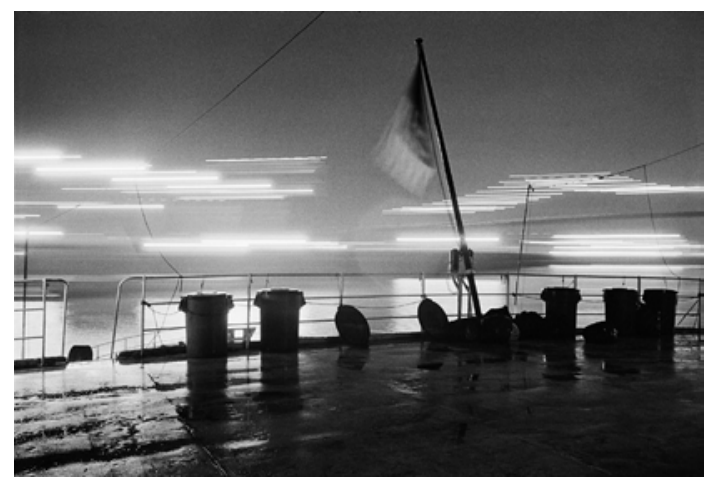

Fig. 25. Leaving Baton Rouge, Louisiana, November 18, 1997

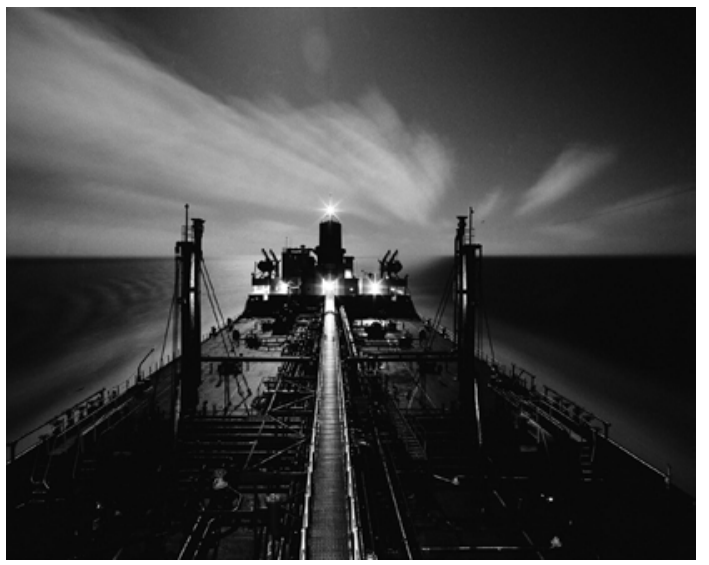

Fig. 26. Untitled, page 37 
Later, we learn that:

Workers then place the [red hot] rebar [from the ship's hull] on a cooling pile for the rest of the night. [...] In the approaching dawn, one can see here and there a worker sleeping on a pile of cooling rebar after completing his shift ( Fig. 27 ); does he dream of the soft grass in the fields of home ( Fig. 28 ) (pp.146-47)?

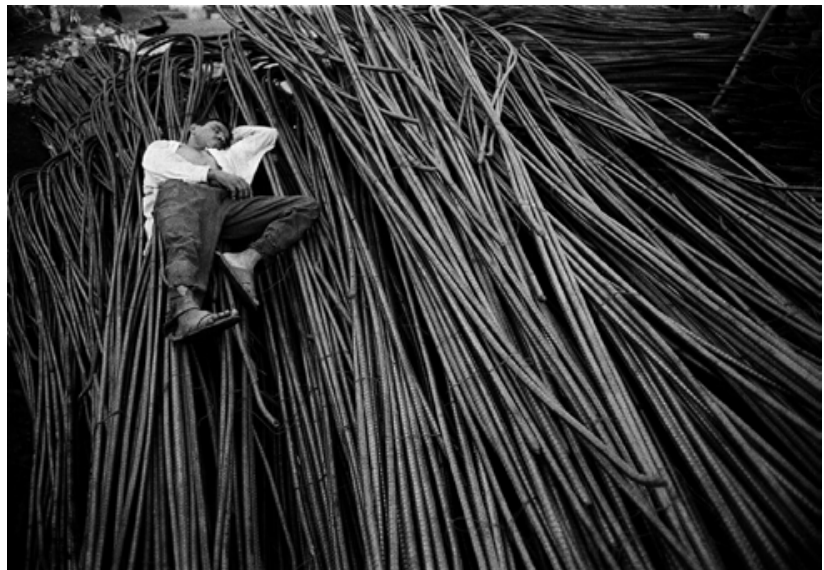

Fig. 27. Cooling rebar, end of the night shift

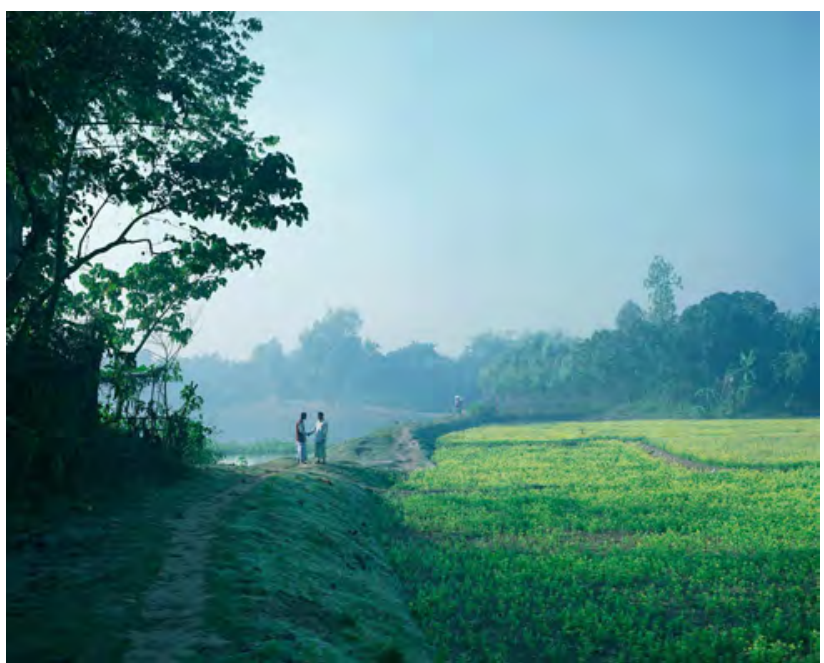

Fig. 28. Shakdahoh, Bogra District, Bangladesh

But the most powerful form of transcendent reincarnation is the transformation of the ship's raw materials - mostly steel, brass, and copper-into works of art. Fig. 29 depicts the burning off of rubber casings to expose the copper cables beneath. And now in Fig. 30 we view but one of the countless works of art made from brass recycled from ships. This is, however, a very particular and most germane work of art: it is the Hindu god Shiva Nataraj or Shiva King of Dance who performs the Tandavam or dance to destroy and recreate the universe, thereby incarnating - himself, the very emblem of death - the very theme of reincarnation and renewal. 


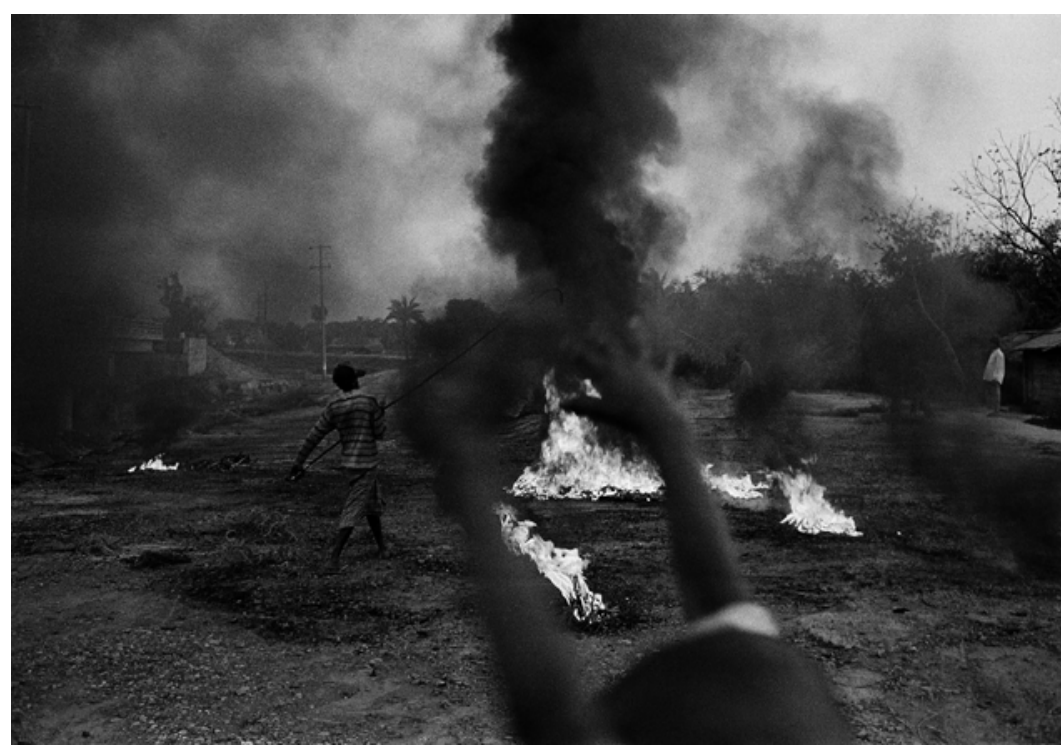

Fig. 29. Burning rubber casting off copper wire

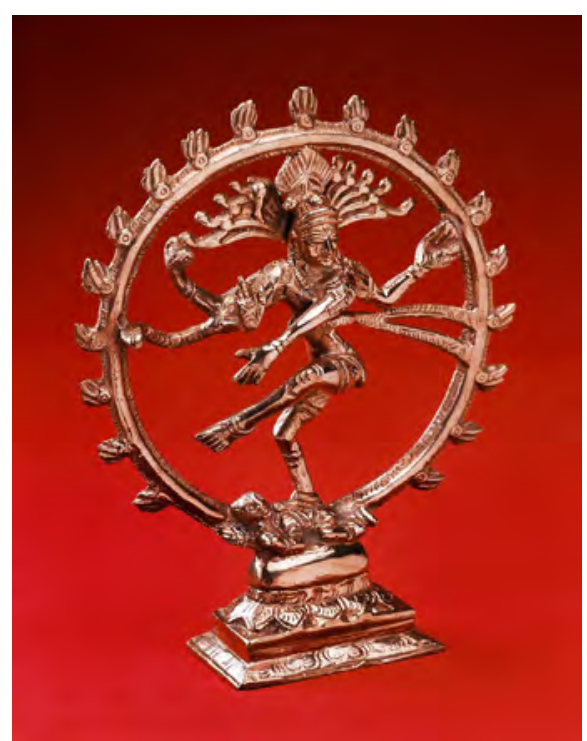

Fig. 30. Shiva Nataraj, dancing to destroy and recreate the universe

I want to suggest that what Cambon both recognizes as transcendence and recreates in his book as transcendent is the "ascending beyond" or, in Hegel's famous term, the Aufhebung or sublation, of opposites such as the opposites of life and death through reincarnation. Cambon quotes Joseph Conrad, "How slow had been the days of passage and how soon they were over" (p.118).

Given the topic of this volume of INTERFACES, the most important Aufhebungen that Cambon effects are between image and word, but also between space and time, which are, of course, related to image and word. As an aside, it's important to note that space and time, as Kant reminds us in the first critique, are the very categories of being; in sublating space and time, Cambon transcends quotidian being. Cambon also wonderfully depicts the Aufhebung of past and present, memory and forgetting, but I need to confine my observations to image and word / space and time. Even here, a few examples will have to suffice. 
The first is remarkably succinct. First the image_-Figure 31.

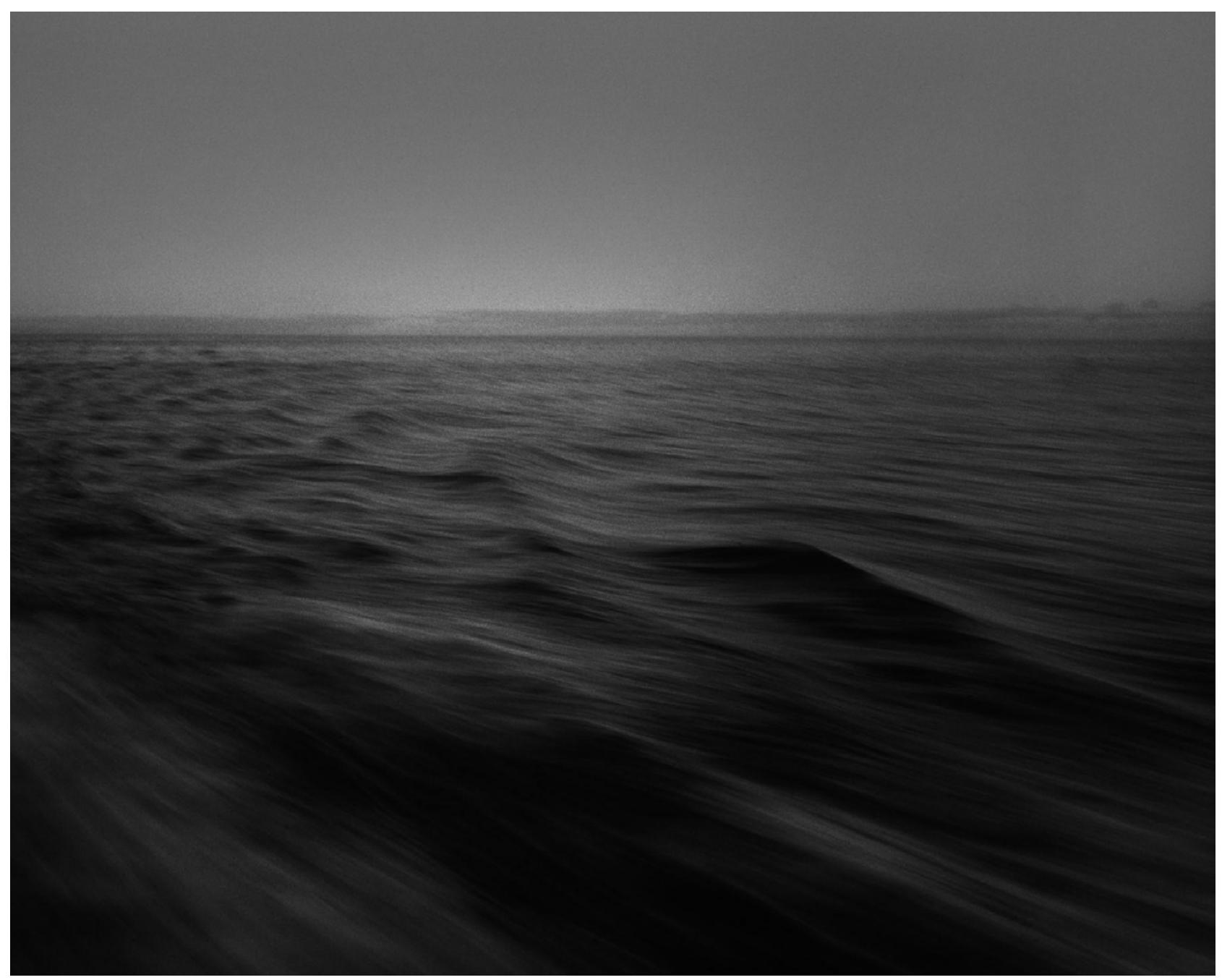

Fig. 31. Untitled, pages 32-33 
Now the words:

[The sea] is splendid and also terrifying. [...] Standing alone, leaning against the rail, [I find it] impossible not to look down at the rich, deep-blue water, and wonder how easy it would be to fall in, to be lost in this vast space. Even in the calmest of seas, the ocean remains a threat that forms a constant part of one's thoughts (p.110).

I call your attention to just one word, the temporal marker, "constant." It's simply genial. With that single word, the static image of the sea we view before us enters time, and for all time-constantly. What I've titled a textual illustration of image is also, then, a kind of reverse ekphrasis - not the creation of image in words, but the temporalizing of image via narrative, a via narrativa.

Let's take another example, the image from the cover of the book Fig. 1. On first glance, this is an electrifying, but also confusing image. Whence the clouds arising from the ship? Is there an explosion? Yes and no. If you look carefully, you'll see a gaping, rectangular hole in the ship's hull which has been cut by the shipbreaking welders. The severed, hundred-ton slab of steel has just fallen to the ground. Let's listen to the illustration:

The deck shakes; the steel groans as it twists free, falling slowly and heavily through the air. It lands with a resounding, deep thud! which makes the ground bounce underfoot like a trampoline; the sound of the impact echoes off the neighboring hulls like a cannon shot. Mud sprays for many yards and a rising cloud of dust envelops the area. It settles with a brief pitter-patter of falling steel chips and slag that sounds like a momentary rainstorm (p.137).

Think, by contrast to this passage, of the locus classicus for ekphrasis-Homer's depiction of Achilles's shield in Book 18 of the Iliad. As is his wont to do from time to time in his epics, Homer wants to arrest his tempestuous narrative flow; the depiction of Achilles's shield is dominated by the stasis of nouns; even the verbs are mostly static_- "stands," "pleads," etc. This passage from Shipbreak, however, is dominated by verbs, verbs, moreover, that form a definite narrative sequence that catapults the captured image of the ship into time: "groans, twists, falling, lands, bounce, echoes, sprays, settles, sounds."

What's particularly striking about both these examples, the sea and the ship being broken, is that, powerful as, in both instances, image and words are separately, the sum of image and words is far greater than each magnificent part. There occurs what the German poet Goethe describes as a 
"Wechselwirkung" or "exchange effect." The fact that image and the illustrative text are separated, often by as many as a hundred large folio pages, forces the brain into a back and forth movement that transcends time (the time between viewing the image and reading the words or text) and space (the literal distance in the book between image and text). Gerard Manley Hopkin's poem "Windhover" comes to mind, where the rapid movement of wings creates a hovering stasis.

To employ a different metaphor, what is created is a mental isosceles triangle ( Fig. 32 ), whereby the base of the triangle is the distance between image and word, and each leg-image and word - of the triangle ascends to the converging apex that is the transcending tertium comparationis (or third thing compared to) formed by the exchange effect between image and word.

As part of the transcending cycle and recycle of death and regeneration, Cambon relates a trenchant personal story that took place on the bay near his childhood home in Maine:

My brother and I pulled in the oars, and as the canoe [note the ship motif] coasted to a standstill, there was only

Transcending Tertium Comparationis (third thing compared to)

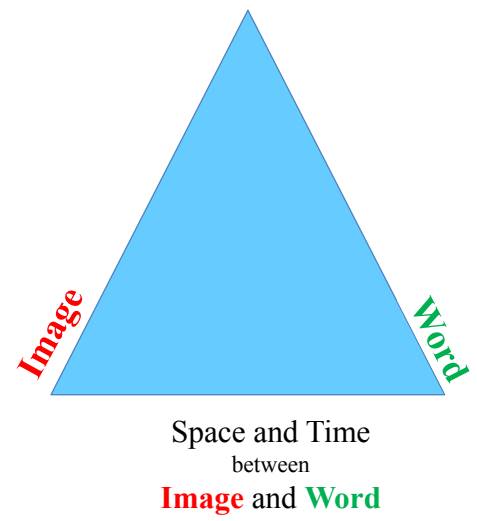

Fig. 32. Pages 148-149 quiet. My mother opened a small tin, and poured ashes which were once my father into the opaque gray-green water of the bay. They saturated in the water for a brief moment, and then vanished instantly and fully. It was if a primal source from the deep had claimed them. His life was surrendered to a larger process. Our tears, of grief and then also of consolation, followed him into that ocean (pp.148-49).

I find particularly powerful and human the move from grief to consolation.

Let me share with you a surprisingly related image Fig. 33. What you're looking at are the last two pages of the main narrative (there is a brief epilogue called "Return"). On the left-hand side, see the three waves that, as we noted before, serve as a type of divider or chapter marker. They run 


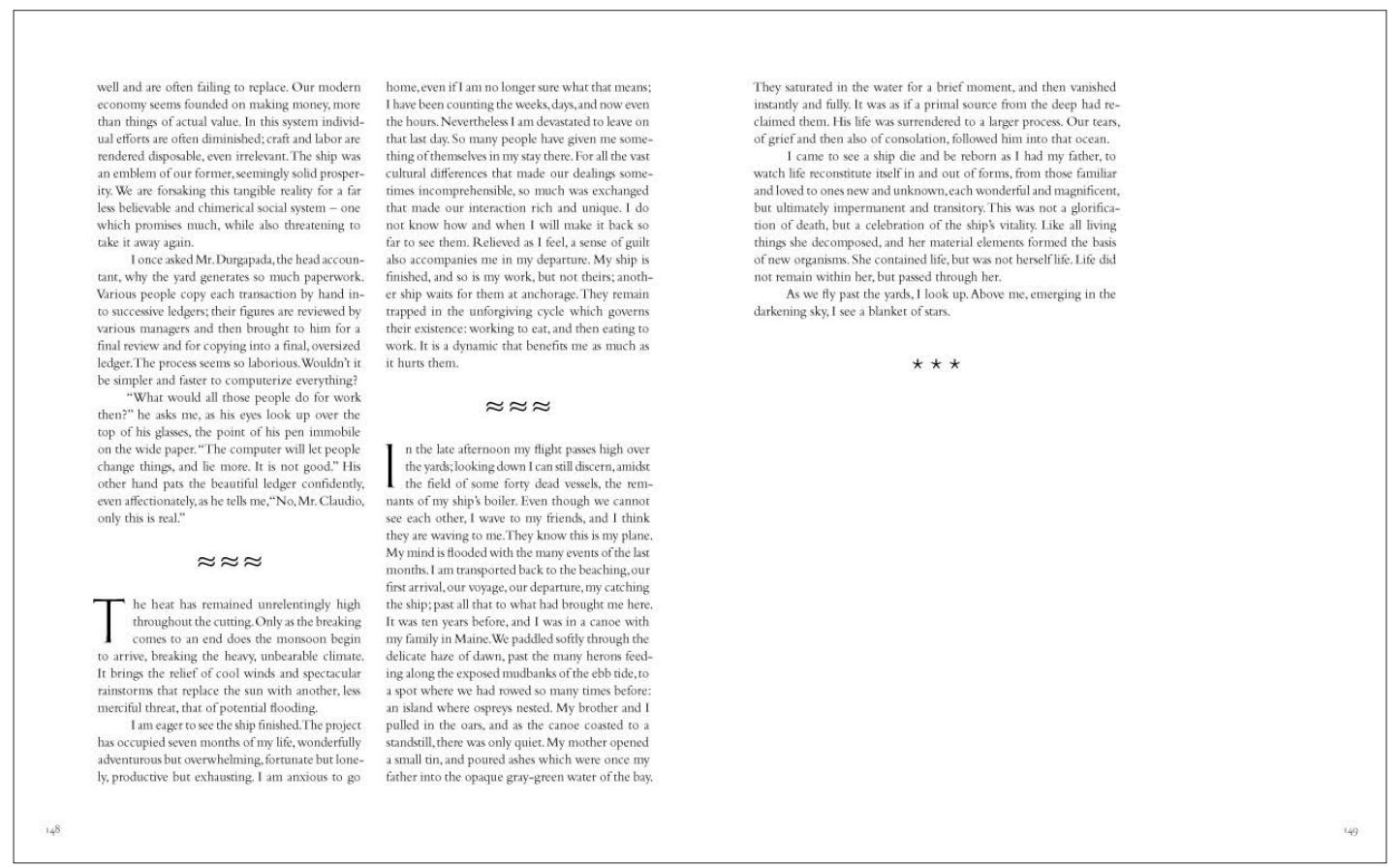

Fig. 33. Shipbreak, pages 148-149.

throughout the main narrative, but at the end we have instead the three stars. We're confronted once more with the interaction of movement or time represented by the waves and the relative stability or space depicted by the stars, but there is a hidden reference here as well.

As Cambon shared with me, the three stars allude to the three great canticles of Dante's Divine Comedy, for all three sections, the Inferno, Purgatorio, and Paradiso, end in the word stelle or stars, as does, parenthetically Cambon's narrative. In particular, the stars point to Book X of the Inferno where Dante encounters the father of one of his best friends, the famous poet Guido Cavalcanti. The father demands to know why his son is not accompanying Dante through hell, and Dante gives a vague reply, but as Cambon's father, a well-known Dante scholar, once explained: in his answer, Dante mimics the rhyme scheme of one of Cavalcanti's most famous poems, as if to say, "I carry your son and my friend with me in my verse." 
I think Cambon suggests that, for those of us open to this type of secular transcendence, we carry our loved ones, living or dead, with us just as Cambon's deceased father is reincarnated in the words and images of Shipbreak and statues of the god of destruction and recreation are fashioned out of the dead ship's recycled brass. Allow me to leave you with this image ( Fig. 34 )of a "[c]row's nest made entirely from wire stolen from the shipbreaking yards" (p.103), emblematic of material reincarnation and birth from death, which are Shipbreak's driving leitmotifs.

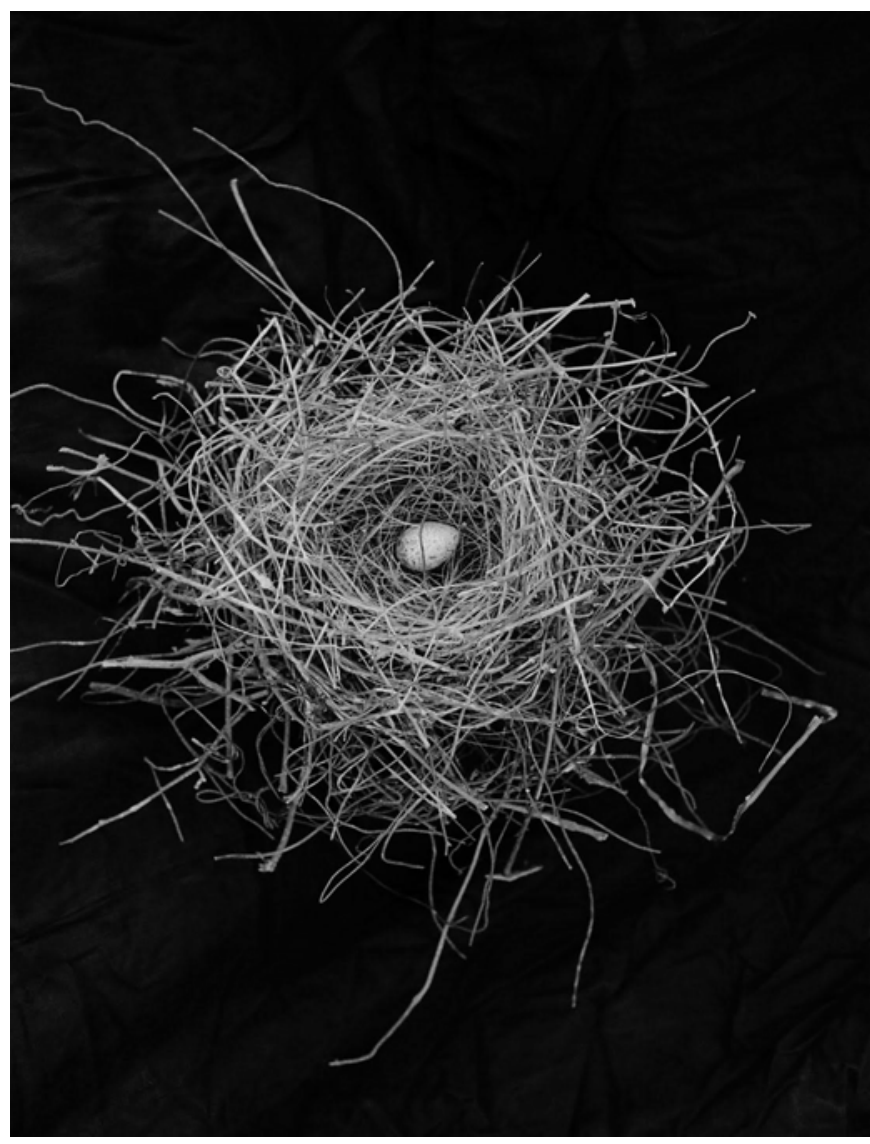

Fig. 34. Crow's nest made entirely from wire stolen from the shipbreaking yards 


\section{Work Cited}

CAMBON, Claudio. Shipbreak. Zurich: Edition Patrick Frey, 2015. 


\section{List OF ILLUSTRATIONS}

Except for Fig. 21, which is courtesy of Bethlehem Steel Corporation, all photographs are by Claudio Cambon. Cambon holds the exclusive copyright and no photograph or part of a photograph may be reproduced without the express written consent of Claudio Cambon.

Fig. 1. Shipbreak, Jacket Cover

Fig. 2. Shipbreak, pages 144-145

Fig. 3. Roger Organ, Chief Cook and Chief Steward

Fig. 4. June Emerson, Assistant Cook

Fig. 5. 'Papa' John Wallace, Bosun

Fig. 6. Out on the fantail after dinner

Fig. 7. Heading down the Mississippi River

Fig. 8. South Atlantic

Fig. 9. Crew's mess, Christmas Eve 1997

Fig.10. Longshoremen board the SS Minole at anchorage off Kutubdia Island, Bangladesh, December 27, 1997

Fig. 11. Untitled, pages $48-49$

Fig. 12. Inj.d workers (1)

Fig. 13. Offloading the ship's contents (1)

Fig. 14. Offloading the ship's contents (2)

Fig. 15. Kholil, age 11, carries a bedframe

Fig. 16. 'Wire carriers' move cable to the ship to retrieve a felled chunk

Fig. 17. Loaders, monsoon

Fig. 18. Loaders, frieze

Fig. 19. Inj.d workers (2)

Fig. 20. Anchor chain paid out

Fig. 21. Launch day, Sparrow's Point Shipyard, Baltimore, Maryland, November 1961

Fig. 22. Untitled, pages 58-59.

Fig. 23. The beaching of the SS Minole, January 14, 2.20 PM, Lalbagh, Bangladesh

Fig. 24. Noah Tanihu, AB Seaman

Fig. 25. Leaving Baton Rouge, Louisiana, November 18, 1997

Fig. 26. Untitled, page 37

Fig. 27. Cooling rebar, end of the night shift

Fig. 28. Shakdahoh, Bogra District, Bangladesh

Fig. 29. Burning rubber casting off copper wire

Fig. 30. Shiva Nataraj, dancing to destroy and recreate the universe

Fig. 31. Untitled, pages 32-33

Fig. 32. Pages 148-149

Fig. 33. Crow's nest made entirely from wire stolen from the shipbreaking yards 